\title{
Conomics
}

\section{Monopoly Innovation and Welfare Effects}

\author{
Shuntian Yao \\ Nanyang Technological University, Singapore \\ Lydia Gan \\ University of North Carolina at Pembroke
}

\begin{abstract}
Please cite the corresponding journal article: http://www.economics-ejournal.org/economics/journalarticles/2010-27
\end{abstract}

\begin{abstract}
In this paper we study the welfare effect of a monopoly innovation. Unlike many partial equilibrium models carried out in previous studies, general equilibrium models with non-price-taking behavior are constructed and analyzed in greater detail. We discover that technical innovation carried out by a monopolist could significantly increase the social welfare. We conclude that, in general, the criticism against monopoly innovation based on its increased deadweight loss is less accurate than previously postulated by many studies.
\end{abstract}

JEL D50; D60

Keywords Monopoly; social welfare; technical innovation; general equilibrium

Correspondence Lydia Gan, School of Business, P.O. Box 1510, One University Drive, University of North Carolina at Pembroke, Pembroke, NC 28372-1510, USA; email: lydia.gan@uncp.edu 


\section{INTRODUCTION}

Economic literature abounds as far as studies related to the welfare losses resulting from monopolization are concerned. Most of them, however, are analyzed with partial equilibrium models. Many authors' attacks against monopoly conditions are based on the deadweight loss effect. As for technical innovation, they argue that while innovation reduces the monopolist's marginal cost and increases the consumer surplus and producer surplus in the monopoly market, it causes a much bigger deadweight loss than before; and because more resources are seized from the other industries by the monopoly and misallocated, the total welfare effect can be negative. In this paper, we attempt to discuss this issue with a general equilibrium model. As shall be seen from the following analyses, unlike the suggestion by some authors as mentioned above, we show that technical innovation by a monopolist actually enhances the general social welfare.

\section{LITERATURE REVIEW}

Harberger (1954) was one of the pioneers in quantifying welfare losses due to monopoly. By adopting a partial equilibrium model that computes welfare losses in terms of the profit rate and the price elasticity of demand in an industry, he estimated welfare losses from monopoly in the United States in 1954 to be relatively insignificant (approximately $0.1 \%$ of GNP), and economists like Schwartzman (1960), ${ }^{1}$ Leibenstein (1966), Bell (1968), Scherer (1970), Shepherd (1972), and Worcester (1973) have confirmed his results.

\footnotetext{
${ }^{1}$ Using similar estimates as Harburger, Schwartzman (1960) provided concurring conclusions that the welfare loss from monopoly had been small, and that income transfers resulting from monopoly were small in the aggregate. Even when the elasticity of demand is assumed to be equal two, the welfare loss probably was still less than 0.1 percent of the national income in 1954.
} 
Harberger's (1954) findings minimizing welfare loss resulting from monopoly were met with considerable criticism. Stigler (1956) and Kamerschen (1966) argued that welfare losses due to monopoly pricing might be greater than what Harberger (1954) and Schwartzman (1960) computed. Stigler (1956) used Harberger's (1954) welfare model and his own estimates of profits, and assumed a range of reasonable values for the elasticity of demand. He thought the limits within which the monopoly welfare losses fell were very large, depending on the extent of actual monopoly power. Using data for the years 1956-1957 and 1960-1961, Kamerschen (1966) proposed that the welfare costs under monopoly power and mergers had been understated in the earlier studies. Much of the earlier work still essentially followed Harberger's (1954) methodology, except for Bergson (1973), who criticized Harburger's partial equilibrium framework, and put forward a general equilibrium model as an alternative. Bergson (1973) showed that the estimated welfare loss was heavily dependent on the value of other parameters, such as the elasticity of substitution and the distribution of price cost ratios, and his results showed that the welfare losses from monopoly were quite large. Bergson's (1973) estimates of maximal welfare loss, though, were countered by others, particularly Carson (1975) and Worcester (1975).

Carson (1975) introduced a three-sector economy and estimated a 3.2 percent maximum welfare loss due to monopoly, which was considerably bigger than Harberger's (1954) and Schwartzman's (1960) calculations, but considerably less than Bergson's (1973) maximum estimate. Based on Harburger's model and using disaggregated annual data 
for specific firms, Worcester (1973) presented a "maximum defensible" estimate in the private sector of the U.S. economy during 1956-1969 and concluded that welfare loss as a result of monopolization was insignificant. Hefford and Round (1978) later accounted for the welfare cost of monopoly by applying Harberger's (1954) estimates and Worcester's (1973) approach in the Australian manufacturing sector for the period 1968-69 to 1974. Their results too suggested that only a relatively small proportion of GDP at factor cost was accounted for by welfare losses as a consequence of monopoly power.

In contrast, using three independent methods and data sets, Parker and Connor (1979) estimated the consumer loss caused by monopoly in the U.S. food-manufacturing industries in 1975. They found that consumer losses due to monopoly were around US\$15 billion or approximately a quarter of U.S. GNP. Virtually all of the consumer loss was attributed to income transfers, and 3\% to $6 \%$ was the result of allocative inefficiency. Supporting this, Jenny and Weber (1983) showed the sensitivity of this measure of welfare loss based on the French economy. They found considerable allocative welfare losses, between $0.85 \%$ and $7.39 \%$ of GDP, and the welfare loss due to X-inefficiencies was as high as $5 \%$ of GDP. However, their estimates were highly tentative due to a lack of data quality and methodological difficulties.

In addition, Cowling and Mueller (1978) obtained empirical estimates of the social cost of monopoly power for both the United States and the United Kingdom. Using a partial equilibrium framework, they proved that the costs of monopoly power on an individual firm basis were generally large. Attacking such models as yielding overestimates in terms 
of welfare losses, Littlechild (1981) introduced a model in an uncertain environment and argued that windfalls and innovation were more important than monopoly power. He suggested that works involving a long-run equilibrium framework in analyzing monopoly often failed to include any neutral or socially beneficial interpretation of monopoly.

Friedland (1978) estimated the welfare gains from economy-wide de-monopolization in a general equilibrium setting and found that the true welfare loss was consistently lower than the partial deadweight loss. Specifically, the size of the welfare gains was dependent on the extent of the product substitutability between the monopoly and competitive firms. The greater the substitutability, the greater the welfare gains and the less the difference between partial and general equilibrium estimates. This result was supported by Hansen (1999), who examined the second-best antitrust issues related to the accuracy of estimating the true welfare loss. He too found that the estimate of deadweight loss under partial equilibrium was larger than the true loss and the difference between the two increased as the specific monopolist being considered became larger. More recently, by adopting a two-good general-equilibrium monopoly production model, Kelton and Rebelein (2003) found that social welfare under monopoly was lifted beyond that of social welfare when perfect competition prevailed. This was especially true if the productivity for the monopolistically produced good is relatively low while the benefit of the good is relatively high. Their results showed that the monopoly leads to higher equilibrium price and lower equilibrium quantity, generating a smaller welfare for nonmonopolists, and a larger welfare for monopolists than with perfect competition. 
As mentioned earlier, some economists proposed that the traditional analysis of monopoly pricing underestimated the social costs of monopoly. Under the perfectly discriminating model, Tullock (1967), Krueger (1974), and Posner (1975) argued that since the whole rent might be dissipated in a competitive process, the full monopoly profit should be added to the social cost of monopoly. Tullock (1967) maintained that the social costs of monopoly should include resources used to obtain monopolies and their opportunity costs while Posner (1975) argued that they should include the high costs of public regulation. Koo (1970) also asserted that other than the loss of consumers' surplus net of the monopolist's gain in profits, the social opportunity loss of the monopolist as a result of the inefficient use of resources should be included in calculating the social cost of monopoly. Even if economies of scale result in lower production costs, the opportunity loss to society because of operating below optimum still exists. However, Shepherd (1972) claimed that the net social loss stemmed from the failure of the monopoly to price efficiently, and not from the resulting loss as a consequence of the monopolization of a competitive industry. Lee and Brown (2005) thought the conventional deadweight loss measure of the social cost of monopoly ignored the social cost of inducing competition. Using an applied general equilibrium model, they proposed a social cost metric where the benchmark is the Pareto optimal state of the economy instead of simply being competitive markets.

Oliver Williamson (1968a, 1968b, 1969a, 1969b) investigated the welfare trade-offs related to horizontal mergers. Merger can result in higher efficiency and lower costs, or greater market power and higher prices. Welfare gains associated with reductions in cost 
typically outweighed the welfare losses imposed on consumers by the greater market power, thus, leading to a net increase in social welfare. Innovation enables monopolists to lower their costs, to expand their output and to reduce their prices; hence it is conventional to conclude that social welfare unambiguously increases as a result. However, DePrano and Nugent (1969) pointed out that in Williamson's (1968a) model, a fixed value for elasticity was used, but if a merger resulted in a movement along the demand curve instead of a shift of the demand curve, the value of the elasticity would be different. They further showed that if elasticity factors were low, it would be unlikely for a small merger to actually experience positive welfare effects.

Geroski (1990) further listed three reasons to expect a negative direct effect of monopoly on innovation: (1) the absence of active competitive forces, (2) an increase in the number of firms searching for an innovation, and (3) incumbent monopolists enjoying a lower net return from introducing a new innovation (Arrow, 1962; Fellner, 1951; Delbono and Denicolo, 1991). In addition, Reksulak et al. (2005) argued that cost-saving innovation raised the opportunity cost of monopoly. As a monopolist with market power became more efficient, greater amounts of surplus were sacrificed by consumers since the former increasingly failed to produce the new and larger competitive output. Thus, innovation elevates the social value of competition by raising the deadweight cost of monopoly. They further contended that even without a rise in market power, the consumer welfare sacrificed under the monopolist would still be larger than under the prevalence of competitive firms. In evaluating the monopoly-related welfare losses, Kay (1983) incorporated factors of production in a general equilibrium context and found that the 
summation of partial equilibrium estimates was likely to be inaccurate as an indicator of summed welfare costs. In the case where there were no constraints on the exercise of monopoly power, simple estimates for summing up the losses could be derived from the general equilibrium model, and these estimates suggested that welfare losses were potentially large.

Some literature addresses the labor-managed behavior of a monopolist in a partial equilibrium setting. According to Hill and Waterson (1983), the labor-managed industry equilibrium produced less output, hence less welfare, than its profit-maximizing counterpart if firms were symmetric. Neary $(1984,1985)$ showed that small levels of output could lead to an increased number of firms in labor-managed equilibrium if firms were asymmetric in relation to technology and/or demand. Using a general equilibrium model, Neary (1992) showed that under certain circumstances the equilibrium of the labor-managed economy could include more firms and result in higher welfare than the profit-maximizing one. If profits were positive, the labor-managed firms would not provide full employment. The entry of new firms can reduce the unemployment and the wage rate leading to lower total utility, but more utility from consumption could lead to a greater total utility.

We now present our model with capital as the single input in the next section. Then, in section 4 , we consider a numerical example, and a brief concluding remark follows in section 5 . 


\section{A MODEL WITH CAPITAL AS THE SINGLE INPUT}

Consider a two-sector economy with a competitive industry that includes many firms and an industry with a single-firm monopoly. The competitive industry consists of $m$ identical small firms, of which each produces the same product good 1, using the same input of natural resources (for example, land, and it will be referred to as capital), having the same production function $q=\phi(k)$, where $k$ is the amount of capital input. The monopolist produces good 2 with the same capital input, and its production function is $Q$ $=\Phi(K)$.

There are $M$ identical consumers, each having the same utility function $u=u\left(x_{1}, x_{2}\right)$, and where $x_{j}$ is the amount of good $j$ consumed, $j=1,2$. Each consumer has an equal profit share from each and every firm, and all shares combined together comprise the first part of his income. The total amount of natural resource available in this economy is $C$, and each individual has an equal share of ownership. The second part of income for each consumer is therefore from renting his natural resource to the firms.

Let $K$ be the amount of capital employed by the monopolist, and $k$ the amount of capital demanded by each competitive firm. Because capital does not directly generate consumption utility, every single individual is ready to rent out his capital share to the firms as long as the rental price is positive. As a result, the rental price of the capital must clear the capital market: $K+m k=C$. In other words, when the monopolist chooses an amount $K$ of capital, the rental price of the capital will be adjusted until each competitive 
firm in the first industry chooses $k=\frac{C-K}{m}$ as capital input for profit maximization. We denote the capital rental price by $v(K)$. Therefore the decision of the monopolist is in essence a strategic decision, and this is the main difference between our model and the classical GE model in which every individual is just a price-taker.

On the other hand, the price of good 2 depends on the quantity produced by the monopolist, which in turn depends on the capital amount he employs. As a result the price of good 2 depends on $K$, and we write it as $P(K)$. As for the competitive industry that produces good 1, each single firm is a price taker in both the output market and the input market, taking the price of its output and the capital rental price as given. For simplicity, in the following discussion good 1's price $p$ is normalized to 1 as the numeraire, and $v(K)$ and $P(K)$ are all measured relative to it.

The decision of the monopoly is to choose the capital stock $K$ such that:

$$
\operatorname{Max} \Pi=P(K) \Phi(K)-v(K) K
$$

Note that the price $P(K)$ of good 2 depends on $K$-- it is not viewed as given as in most classical general equilibrium models. It is this non-price-taking feature that makes our model different from other classical general equilibrium models, and as a result of that, it makes the required mathematical computation more complicated.

The decision of each small firm is: 


$$
\operatorname{Max} \pi=\phi(k)-v(K) k
$$

Given (1) and (2), the profit income for each consumer is thus:

$$
\frac{\Pi+m \pi}{M}=\frac{P(K)-v(K) K+m(\phi(k)-v(K) k)}{M}
$$

And the resource rental income for each consumer is:

$$
\frac{v(K)(K+m k)}{M}
$$

The decision of each consumer is thus

$$
\operatorname{Max} u\left(x_{1}, x_{2}\right)
$$

s.t. $\quad x_{1}+P(K) x_{2}=\frac{P(K)-v(K) K+m(\phi(k)-v(K) k)+v(K)(K+m k)}{M}$

Definition 1. An equilibrium of this two-sector economy consists of (i) capital rental amounts $\left(K^{*}, k^{*}\right)$, (ii) a price vector $\left(1, P\left(K^{*}\right), v\left(K^{*}\right)\right)$, and (iii) the individual consumption of goods $\left(x_{1}^{*}, x_{2}^{*}\right)$ such that (a) (1)(2)(3) are solved with $K=K^{*}, k=k^{*}$, $P(K)=P\left(K^{*}\right), v(K)=v\left(K^{*}\right), x_{1}=x_{1}^{*}, x_{2}=x_{2}^{*} ;$ and (b) all markets are cleared: $M x_{1}^{*}=m \phi\left(k^{*}\right), M x_{2}^{*}=\Phi\left(K^{*}\right), m k^{*}+K^{*}=C$. 
Definition 2. A technical innovation by the monopolist is the development of a new production function $Q=\Psi(K)$ such that $\Psi(K)>\Phi(K)$ for all $K$.

What we are going to establish:

Theorem 1. Suppose in the economy as described above, the utility function of each consumer is strongly increasing. Suppose the new production technique $\psi(K)$ is constant returns to scale, or increasing returns to scale when $K \leq C$. And suppose that, after the innovation, the equilibrium output by the monopolist is larger than that which it was before the innovation. Then, ignoring the research and development (R\&D) costs for technical innovation, ${ }^{2}$ the welfare effect of the innovation is positive.

It seems obvious to some economists that technical innovation always leads to higher welfare effects. Their views are based on a partial equilibrium model, in which innovation in one industry will result in higher output in the particular industry but leaving outputs from other industries unaffected. As a result of innovation, consumers will end up consuming more goods produced by the innovating industry without reducing their consumption of the other goods.

\footnotetext{
${ }^{2}$ In our discussion, for simplicity, we do not consider the R\&D costs of technical innovation. The R\&D costs are paid for just one period, while the consumers' utility gains caused by innovation, if they do exist, will last for a lifetime. In this sense the R\&D costs can be neglected if future utility is not too substantially discounted.
} 
However, this partial equilibrium analysis is not precise because the innovation carried out by one industry may change the resource allocation across the whole economy. In other words, more resources will be used by the innovating industry for production, leaving less for the other industries. Therefore in this economy some goods are produced in greater amounts than before the innovation, but some other goods are produced in smaller amounts than before the innovation. After the innovation, consumers consume greater amounts of some goods but smaller amounts of the others. Thus the total welfare effect is unclear. That explains why some other economists attempt to argue that monopoly innovation may lead to negative welfare effects. According to their belief, when more resources are used by the monopoly, it will significantly increase the deadweight loss. At the same time, the outputs produced by the other industries can also be significantly reduced. In terms of social welfare, this may not be compensated sufficiently by the increase in the monopoly outputs, and will eventually lead to a reduction of consumer utility.

It would be easier to show that innovation leads to higher welfare if the innovation were carried out by all the firms in a competitive industry. This result can be derived directly from the First Welfare Theorem. However, due to the existence of monopoly power in our case, the First Welfare Theorem no longer applies. In order to prove this result, we need to make stronger assumptions and provide more subtle arguments -- though the procedure looks similar to the proof of the First Welfare Theorem. 
Proof: In the following section, we use * and $* *$ to denote respectively the equilibrium quantities before and after the innovation. According to our assumption, it holds that $\Psi\left(K^{* *}\right)>\Phi\left(K^{*}\right)$. There are two cases: (a) $K^{* *} \leq K^{*}$ but $\Psi\left(K^{* *}\right)>\Phi\left(K^{*}\right)$ (due to higher productivity after the innovation), and (b) $K^{* *}>K^{*}$.

In case (a), at the equilibrium, good 1's total quantity is not reduced because the total capital utilized by the competitive industry is either the same as or bigger than before the innovation, while on the other hand the amount of good 2 produced in the economy is larger. Obviously in this case each consumer achieves a higher equilibrium utility.

The argument for case (b) is a bit more complicated. Assume that, with the new production technique of $\Psi$, the new equilibrium of this two-sector economy is characterized by (i) $\left(K^{* *}, k^{* *}\right)$, (ii) $\left(1, P\left(K^{* *}\right), v\left(K^{* *}\right)\right)$, and (iii) $\left(x_{1}^{* *}, x_{2}^{* *}\right)$. We need to show that $u\left(x_{1}^{* *}, x_{2}^{* *}\right)>u\left(x_{1}^{*}, x_{2}^{*}\right)$.

Assume by contradiction that this conclusion were not true and thus $u\left(x_{1}^{* *}, x_{2}^{* *}\right) \leq u\left(x_{1}^{*}, x_{2}^{*}\right)$. We first consider a feasible allocation of the economy under the production technique of $\Psi$. Imagine the monopolist and all the competitive firms no longer care for profit-maximization and maintain the optimal decision like in the old days with $K=K^{*}$ and $k=k^{*}$, then while each competitive firm produces the same output of good 1 also as in earlier times, the monopolist now produces a bigger output of good 2 because of the new technology. Assume that the goods are equally shared by each 
consumer. Then each consumer consumes the same amount of good 1 as before but a bit more of good 2 than in by-gone times. Let the consumption vector of each consumer be $\left(x_{1}^{*}, x_{2}^{\prime}\right)$. In view of the strongly increasing property of the utility function $u$, we must have $u\left(x_{1}^{*}, x_{2}^{*}\right)<u\left(x_{1}^{*}, x_{2}^{\prime}\right)$, which, together with our assumption in the beginning of this paragraph, implies $u\left(x_{1}^{* *}, x_{2}^{* *}\right)<u\left(x_{1}^{*}, x_{2}^{\prime}\right)$.

According to the definition of equilibrium, $\left(x_{1}^{*}, x_{2}^{\prime}\right)$ must not be feasible under the price system $\left(1, P\left(K^{* *}\right), v\left(K^{* *}\right)\right)$ and the individual income at the new equilibrium, i.e.,

$$
\begin{aligned}
x_{1}^{*}+P\left(K^{* *}\right) x_{2}^{\prime} & >\frac{P\left(K^{* *}\right) \Psi\left(K^{* *}\right)-v\left(K^{* *}\right) K^{* *}+m\left(f\left(k^{* *}\right)-v\left(K^{* *}\right) k^{* *}\right)+v\left(K^{* *}\right) C}{M} \\
& =\frac{P\left(K^{* *}\right) \Psi\left(K^{* *}\right)+m f\left(k^{* *}\right)}{M}
\end{aligned}
$$

On the other hand, we have, $x_{1}^{*}=\frac{m f\left(k^{*}\right)}{M}, x_{2}^{\prime}=\frac{\Psi\left(K^{*}\right)}{M}$, and therefore

$$
x_{1}^{*}+P\left(K^{* *}\right) x_{2}^{\prime}=\frac{P\left(K^{* *}\right) \Psi\left(K^{*}\right)+m f\left(k^{*}\right)}{M}
$$

Combining (4) and (5) one derives:

$$
P\left(K^{* *}\right) \Psi\left(K^{*}\right)+m f\left(k^{*}\right)>P\left(K^{* *}\right) \Psi\left(K^{* *}\right)+m f\left(k^{* *}\right)
$$


Note that

$$
C=K^{*}+m k^{*}=K^{* *}+m k^{* *}
$$

Thus

$$
v\left(K^{* *}\right) K^{*}+m v\left(K^{* *}\right) k^{*}=v\left(K^{* *}\right) K^{* *}+m v\left(K^{* *}\right) k^{* *}
$$

Subtracting (7) from (6) side by side:

$$
\begin{aligned}
& {\left[P\left(K^{* *}\right) \Psi\left(K^{*}\right)-v\left(K^{* *}\right) K^{*}\right]+m\left[f\left(k^{*}\right)-v\left(K^{* *}\right) k^{*}\right]>} \\
& {\left[P\left(K^{* *}\right) \Psi\left(K^{* *}\right)-v\left(K^{* *}\right) K^{* *}\right]+m\left[f\left(k^{* *}\right)-v\left(K^{* *}\right) k^{* *}\right]}
\end{aligned}
$$

However, given the rental price $v\left(K^{* *}\right), k^{* *}$ is optimal capital rental for every competitive firm for profit maximization. As a result the second term in the right hand side of (8) is greater than the second term in its left hand side. We then must have

$$
P\left(K^{* *}\right) \Psi\left(K^{*}\right)-v\left(K^{* *}\right) K^{*}>P\left(K^{* *}\right) \Psi\left(K^{* *}\right)-v\left(K^{* *}\right) K^{* *}
$$

On the other hand, let $\mathrm{a}=\frac{K^{* *}}{K^{*}}>1$. By the assumption of constant returns to scale or increasing returns to scale of $\Psi$, we have $\Psi\left(K^{* *}\right) \geq a \Psi\left(K^{*}\right)$, and as a result, 


$$
P\left(K^{* *}\right) \Psi\left(K^{* *}\right)-v\left(K^{* *}\right) K^{* *}>P\left(K^{* *}\right) a \Psi\left(K^{*}\right)-v\left(K^{* *}\right) a K^{*}>a\left[P\left(K^{* *}\right) \Psi\left(K^{*}\right)-v\left(K^{* *}\right) K^{*}\right]
$$

Note that as a $>1$, a contradiction between (9) and (10) is thus obtained. As a result, in case (b) we must also have $u\left(x_{1}^{* *}, x_{2}^{* *}\right)>u\left(x_{1}^{*}, x_{2}^{*}\right)$. Theorem 1 is thereby proven.

\section{A NUMERICAL EXAMPLE}

Consider an economy with a competitive industry that includes many firms and an industry with a single monopoly firm. The competitive industry consists of $m$ identical small firms, of which each produces the same product good 1, using the same input of natural resources (for example, land, and remember will be referred to as capital), having the same production function $q=\sqrt{k}$, where $k$ is the amount of capital input. The monopolist produces good 2 with the capital input, and its production function is $Q=t K$, where $K$ is the capital input, and $t>0$ is a parameter representing the level of technology.

There are $M$ identical consumers, each having the same utility function $u=\sqrt{x_{1}\left(x_{2}+1\right)}$, where $x_{j}$ is the amount of good $j$ consumed. The asymmetric feature of the utility function implies that good 1 is a subsistence good, the consumption of it being required to survive (for example, basic food); on the other hand, the consumption of good 2 increases the utility from each unit of good 1 consumed; good 2 itself not being a subsistence good. (Note: In reality, a subsistence good such as food is hardly provided by a single private firm. Otherwise for profit maximization the monopolist would charge an extremely high price and would produce a very tiny amount). Each consumer has an equal profit share 
from each and every firm, and all shares combined together consist as part of his income. The total natural resource available in this economy is $C$, and each individual has an equal share. The other part of the income for each consumer is therefore from renting his natural resource to the firms.

Let 1 be the price of good 1 , and let $v(K)$ be the rental rate of capital.

The decision of each small firm is:

$$
\operatorname{Max} \pi=\sqrt{k}-v(K) k
$$

from which one solves $k=\frac{1}{4[v(K)]^{2}}, q=\frac{1}{2 v(K)}$, and $\pi=\frac{1}{4 v(K)}$.

The decision of the monopoly is to choose the capital stock $K$ such that:

$$
\operatorname{Max} \Pi=P(t K)-v(K) K=P(K)(t K)-v(K) K
$$

According to the assumption on profit share, the income of each and every consumer is $\frac{\frac{m}{4 v(K)}+P(K) t K-v(K) K}{M}$. The income from the renting of natural resources for each individual is $\frac{C v(K)}{M}$. It is easy to verify that the individual quantity demand for good 1 and that for good 2 are, respectively: 


$$
x_{1}=\frac{0.5\left[C v(K)+\frac{m}{4 v(K)}+P(K) t K-v(K) K\right]}{M}+0.5 P(K)
$$

$$
x_{2}=\frac{0.5\left[C v(K)+\frac{m}{4 v(K)}+P(K) t K-v(K) K\right]}{M \cdot P(K)}-0.5
$$

The total quantity demanded for good 2 is then:

$$
M x_{2}=\frac{0.5\left[C v(K)+\frac{m}{4 v(K)}+P(K) t K-v(K) K\right]}{P(K)}-0.5 M
$$

For market clearing, it must hold that

$$
t K=\frac{0.5\left[C v(K)+\frac{m}{4 v(K)}+P(K) t K-v(K) K\right]}{P(K)}-0.5 M
$$

from which one can solve

$$
P(K)=\frac{m+4[v(K)]^{2}(C-K)}{4 v(K)(M+t K)}
$$


On the other hand, for capital market clearing:

$$
K+\frac{m}{4[v(K)]^{2}}=C
$$

Thus

$$
4[v(K)]^{2}=\frac{m}{C-K}, \quad v(K)=\frac{\sqrt{m}}{2 \sqrt{C-K}}
$$

Combining these results, we get:

$$
\begin{aligned}
& P(K)=\frac{\sqrt{m(C-K)}}{M+t K} \\
& \Pi(K)=\frac{\sqrt{m(C-K)}}{M+t K} t K-\frac{\sqrt{m}}{2 \sqrt{C-K}} K
\end{aligned}
$$

The first order condition reads:

$$
t^{2} K^{3}+4 t^{2}(C-K) K^{2}+2 M t K^{2}+6 M t(C-K) K-4 M t(C-K)^{2}+M^{2} K+2 M^{2}(C-K)=0
$$

The solution is $K=K^{*}(M, C, t)$.

Note that 


$$
x_{1}=\frac{\sqrt{m(C-K)}}{M}, \quad x_{2}+1=\frac{M+t K}{M}
$$

As a result,

$$
u=\frac{(M+t K)^{1 / 2}[m(C-K)]^{1 / 4}}{M}
$$

Now let us assume that $M=10,000, \mathrm{C}=10,000$, and $m=100$. Then equation (22) becomes,

$t^{2} K^{3}+4 t^{2}\left(10^{4}-K\right) K^{2}+2 \times 10^{4} t K^{2}+6 \times 10^{4}\left(10^{4}-K\right) t K-4 \times 10^{4} t\left(10^{4}-K\right)^{2}+10^{8} K+2 \times 10^{8}\left(10^{4}-K\right)=0$

Assuming the values of $t$ are between the range of 1 to 2 , then solving for the corresponding values of $K$ and $u$ using numerical techniques, the relationship between $t$ and $u$ can be derived as shown (see Figure 1 on page 28 ).

From Figure 1 we observe that $u$ increases together with $t$. Thus we have

Proposition 1. In our model with capital as the single input, as the technology of the monopolist advances while more resources are used by the monopoly instead of by the competitive firms, the social welfare is increased (see Figure 2 on page 29). 


\section{CONCLUSION}

Most of the criticism against monopoly is based on its deadweight loss. With partial equilibrium models, some authors argue that because more resources are used by the monopoly, innovation introduced by a monopolist could generate substantial deadweight loss and hence could lead to negative welfare effects. Our modeling and analysis have proven otherwise. Although our analysis is based on a simple model with some specific assumptions, we believe our conclusion that technical innovations brought about by a monopoly increase overall social welfare is generally correct - as long as the monopoly profits are shared by the vast majority. 


\section{REFERENCES}

Arrow, K. (1962). Economic Welfare and the Allocation of Resources for Inventions. In

Nelson, R. (ed.), The Rate and Direction of Inventive Activity. Princeton: University Press.

Bell, F. (1968). The Effect of Monopoly Profits and Wages on Prices and Consumers' Surplus in American Manufacturing. Western Economic Journal 6: 233-241.

Bergson, A. (1973). On Monopoly Welfare Losses. American Economic Review 63: 853-870.

Carson, R. (1975). On Monopoly Welfare Losses: Comment. American Economic Review 65: 1008-1014.

Cowling, K. and Mueller, D. (1978). The Social Costs of Monopoly Power. Economic Journal 88: 727-748.

Delbono, F. and Denicolo, V. (1991). Incentives to Innovate in a Cournot Oligopoly. Quarterly Journal of Economics 106: 951-961.

DePrano, M. and Nugent, J. (1969). Economies as an Antitrust Defense: Comment. American Economic Review 59: 947-953.

Fellner, W. (1951). The Influence of Market Structure on Technological Progress. Quarterly Journal of Economics 65: 556-577.

Friedland, T. (1978). The Estimation of Welfare Gains from Demonopolization. Southern Economic Journal 45: 116-123.

Geroski, P. (1990). Innovation, Technological Opportunity, and Market Structure. Oxford Economic Papers 42: 586-602. 
Hansen, C. (1999). Second-best Antitrust in General Equilibrium: a Special Case. Economics Letters 63: 193-199.

Harberger, A. (1954). Monopoly and Resource Allocation. American Economic Review 44: 77-87.

Hefford, C. and Round, D. (1978). The Welfare Cost of Monopoly in Australia. Southern Economic Journal 44: 846-860.

Hill, M. and Waterson, M. (1983). Labor-managed Cournot Oligopoly and Industry Output. Journal of Comparative Economics 7: 43-51.

Jenny, F. and Weber, A. (1983). Aggregate Welfare Loss due to Monopoly Power in the French Economy: Some Tentative Estimates. Journal of Industrial Economics 32: 113130.

Kamerschen, D. (1966). An Estimation of the Welfare Losses from Monopoly in the American Economy. Western Economic Journal 4: 221-236.

Kay, J. (1983). A General Equilibrium Approach to the Measurement of Monopoly Welfare Loss. International Journal of Industrial Organization 1: 317-331.

Kelton, C. and Rebelein, R. (2003). A Static General-Equilibrium Model in Which Monopoly is Superior to Competition. Manuscript. Department of Economics, Vassar College, $\quad$ Poughkeepsie, $\quad$ NY. Available at http://irving.vassar.edu/faculty/rr/Research/monopoverCE.pdf

Koo, S. (1970). A Note on the Social Welfare Loss due to Monopoly. Southern Economic Journal 37: 212-214. 
Krueger, A. (1974). The Political Economy of the Rent-Seeking Society. American Economic Review 64: 291-303.

Lee, Y. and Brown, D. (2005). Competition, Consumer Welfare, and the Social Cost of Monopoly. Discussion Paper 1528. Cowles Foundation for Research in Economics, Yale University, New Haven, CT. Available at http://cowles.econ.yale.edu/P/cd/d15a/d1528.pdf

Leibenstein, H. (1966). Allocative Efficiency vs. "X-Efficiency". American Economic Review 56: 392-415.

Littlechild, S. (1981). Misleading Calculations of the Social Costs of Monopoly Power. Economic Journal 91: 348-363.

Neary, H. (1984). Labor-Managed Cournot Oligopoly and Industry Output: a Comment. Journal of Comparative Economics 8: 322-327.

Neary, H. (1985). The Labor-Managed Firm in Monopolistic Competition. Economica 52: 435-447.

Neary, H. (1992). Some General Equilibrium Aspects of a Labor-Managed Economy with Monopoly Elements. Journal of Comparative Economics 16: 633-654.

Parker, R. and Connor, J. (1979). Estimates of Consumer Losses due to Monopoly in the U.S. Food-Manufacturing Industries. American Journal of Agricultural Economics 61: 626-639.

Posner, R. (1975). The Social Costs of Monopoly and Regulation. Journal of Political Economy 83: 807-828. 
Reksulak, M., Shughart II, W. and Tollison, R. (2008). Innovation and the Opportunity Cost of Monopoly. Managerial and Decision Economics 29(8). DOI: 10.1002/mde.1425.

Scherer, F. (1970). Industrial Market Structure and Economic Performance. Chicago: Rand McNally.

Schwartzman, D. (1960). The Burden of Monopoly. Journal of Political Economy 68: 627-630.

Shepherd, R. (1972). The Social Welfare Loss due to Monopoly: Comment. Southern Economic Journal 38: 421-424.

Stigler, G. (1956). The Statistics of Monopoly and Merger. Journal of Political Economy 64: 33-40.

Tullock, G. (1967). The Welfare Costs of Tariffs, Monopolies, and Theft. Western Economic Journal 5: 224-232.

Williamson, O. (1968a). Economies as an Antitrust Defense: the Welfare Tradeoffs. American Economic Review 58: 18-36.

Williamson, O. (1968b). Economies as an Antitrust Defense: Correction and Reply. American Economic Review 58: 1372-1376.

Williamson, O. (1969a). Allocative Efficiency and the Limits of Antitrust. American Economic Review 59: 105-118.

Williamson, O. (1969b). Economies as an Antitrust Defense: Reply. American Economic Review 59: 954-959. 
Worcester, Jr. D. (1973). New Estimates of the Welfare Loss to Monopoly, United States: 1956-1969. Southern Economic Journal 40: 234-245.

Worcester, Jr. D. (1975). On Monopoly Welfare Losses: Comment. American Economic Review 65: 1015-1023. 


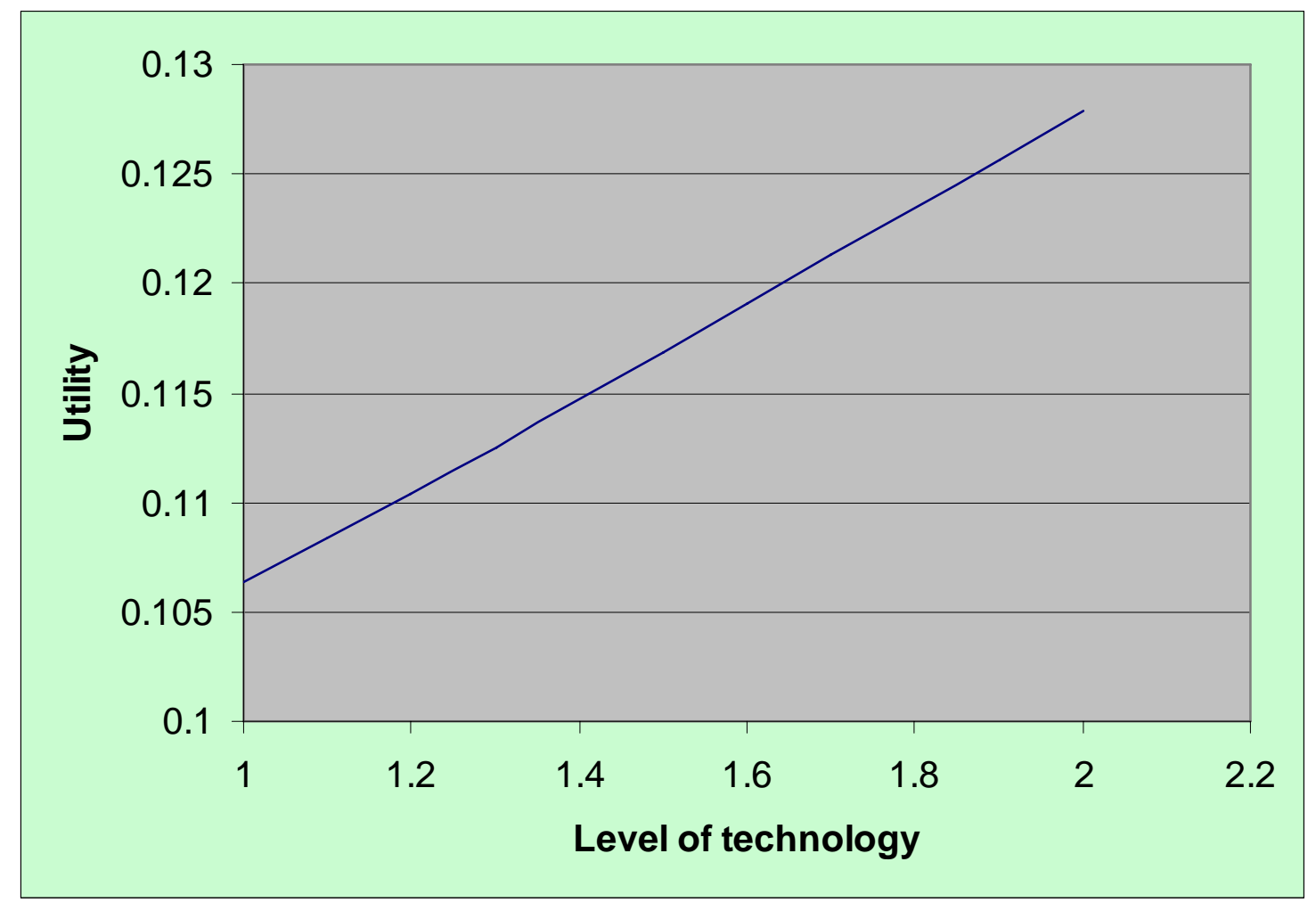

Figure 1. Relationship between the level of technology and utility. 


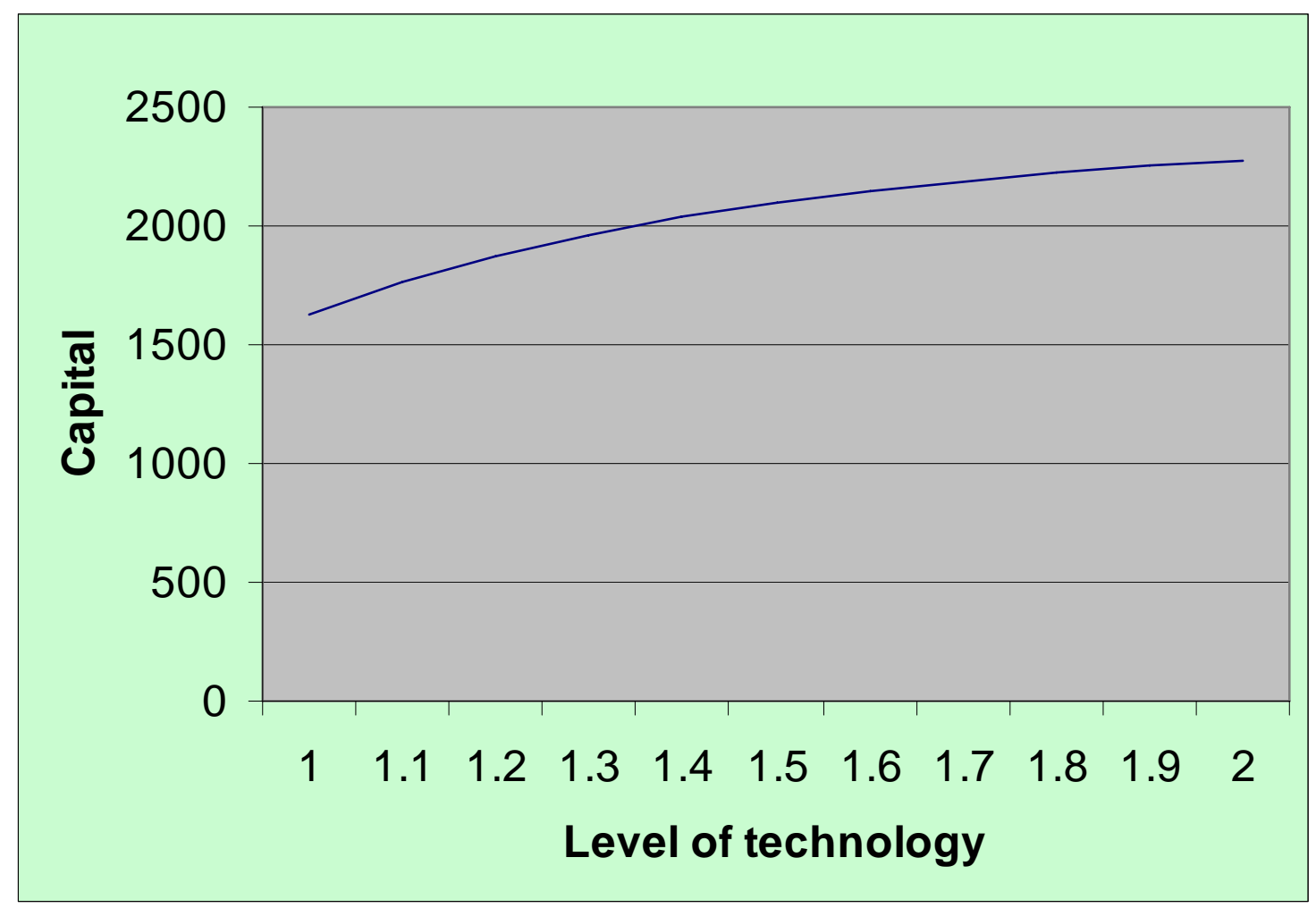

Figure 2. Relationship between the level of technology and capital. 


\section{Conomics}

The Open-Access, Open-Assessment E-Journal

Please note:

You are most sincerely encouraged to participate in the open assessment of this discussion paper. You can do so by either recommending the paper or by posting your comments.

Please go to:

http://www.economics-ejournal.org/economics/discussionpapers/2010-10

The Editor 